\title{
Quality of Academic Service during the COVID-19 Pandemic at the Universitas Muhammadiyah Sinjai
}

\author{
Muhammad Takdir ${ }^{1}$, Baharuddin $^{2}$, Sitti Hardiyanti Arhas ${ }^{3}, \operatorname{Irman}^{4}$ \\ ${ }^{1,2,4}$ Universitas Muhammadiyah Sinjai, Indonesia, ${ }^{3}$ Universitas Negeri Makassar \\ Email: takdirstisip@gmail.com
}

\begin{abstract}
The government, through the ministry of education and culture, urges universities to monitor and assist students in learning from home. the type of research chosen is qualitative research. The data collection techniques used in this study were interviews, observation, and documentation. Meanwhile, the data analysis techniques used were data reduction, data presentation, and verification. Academic services during the COVID-19 pandemic at the Universitas Muhammadiyah Sinjai ran effectively according to the rules that had been set and were running according to the expected goals, this was seen from the service for student proposal examinations, the lecture process, and new student admissions.
\end{abstract}

Keywords: COVID-19, online service, students

\section{INTRODUCTION}

Libraries The world is being shocked by the emergence of the coronavirus disease (COVID-19), which has had a significant impact on changing the world (Asbari et al., 2020; Narmaditya et al., 2020; Suprianto et al., 2020). Starting from the economic, social to daily life aspects, there is almost no dodging the emergence of COVID-19, including public services ( $\mathrm{Li}$ et al., 2020; Miao et al., 2021; Oztig \& Askin, 2020; Tirachini \& Cats, 2020). Since March 2020 , various policies have been issued by the central and regional governments ranging from limiting social relations, calling for work at home, eliminating worship activities and asking people to stay at home, and reducing economic activities outside the home, with many public service agencies limiting services, initiated online services and even stopped all services (Dennison Himmelfarb \& Baptiste, 2020; Shereen et al., 2020).

With the existence of restrictions on public services, especially in the field of government education, the Ministry of Education and Culture (Kemendikbud) made several regulations, including a circular number 36962/MPK.A/HK/2020 Regarding online learning and working at home to prevent the spread of the coronavirus disease (COVID-19), the government, through the Ministry of Education and Culture (Kemendikbud), urges universities to monitor and assist students in learning from home. The savings in operational costs of education that are obtained during the study from home in this circular make it easy for students in the learning process. From the above policy, it can be concluded that the direct services in the higher education institution will automatically switch to an online system (Bao, 2020; Burki, 2020; Murphy, 2020; Toquero, 2020).

When all academicians must carry out work and study activities at home using online remote methods, students and lecturers can no longer carry out face-to-face activities in carrying out learning activities. Therefore it is a very vital institution in supporting learning activities. 


\section{4 | Jurnal Administrare: Jurnal Pemikiran Ilmiah dan Pendidikan Administrasi Perkantoran \\ Volume 8 Issue 1, January-June 2021. Pages 143-148}

must continue to contribute and provide services of relevant and important information sources in supporting teaching and learning activities.

This requires universities to adapt to providing information services and reference sources to all academicians. Online remote services include services for the use of electronic library materials and information literacy. For higher education human resources during the COVID-19 pandemic, this was used to increase competence through continuous professional development. From the description above, it can be concluded that even though there is a COVID-19 pandemic, services at universities will continue to run well if the facilities and infrastructure are met for those who receive services. However, the next problem is the quality of the service, whether it goes according to the wishes of the service provider or according to the wishes of the recipient or the one being served, of course, in measuring or measuring the quality of this system, it is necessary to have indicator indicators to determine the level of success or failure of the service, how the process whether the service is effective or not can be measured by indicators of measuring effectiveness indicators. The objective condition of the service shows that to provide the best service for students there are still many obstacles. This situation cannot be separated from the challenges, namely the existence of an infectious disease called COVID19 which has a major impact on service providers and students who receive services.

An overview of academic services at Universitas Muhammadiyah Sinjai, academic services at the previous at Universitas Muhammadiyah Sinjai was very good, seen from the various services provided to students, such as the admission of new students, implementation of learning, implementation of examinations, as benchmarks related to services provided can be seen from student activities everything was smooth and there were no problems. However, with the COVID-19 disaster, it has had a very significant impact, with policies issued by both the government and the central leadership to prevent the spread of the COVID-19 virus, such as a ban on mass gathering that can cause the spread of the virus, heeding this policy, at Universitas Muhammadiyah Sinjai provides services to students online for all student services amid this difficult time, online services are certainly not young either for people who will provide services or who will receive services

Therefore, this study will examine how the quality of academic services is seen from two sides, namely service amid the Coronavirus disease-19, and paying attention to efforts to prevent the spread of the virus through the health protocol for handling the C-19 virus. Based on this background, the researcher plans to research with the title Quality Of Academic Service during the COVID-19 Pandemic at Universitas Muhammadiyah Sinjai by using a qualitative approach and collecting data and information from several informants directly according to the phenomena that occur at the research location, either through observation or documents related documents.

\section{METHOD}

The type of research chosen is qualitative research. The location of this research will be carried out at the Universitas Muhammadiyah Sinjai. The informants in the research conducted at the Universitas Muhammadiyah Sinjai were prospective students and active students, university leaders, new student admissions committee, proposal exam committee, COVID-19 task force, and lecturers. The data collection techniques used in this study were interviews, 
observation, and documentation. Meanwhile, the data analysis techniques used were data reduction, data display, and verification.

\section{RESULT AND DISCUSSION}

According Educational services are educational services. The word service itself has several meanings, from personal service to serve as a product. Education as a service product is something that is intangible but can meet consumer needs which are processed by using or not using the help of physical products where the process that occurs is an interaction between service providers and service users that has characteristics that do not result in the transfer of rights or ownership. Education is a humanizing process or a process that must be carried out, whether institutionalized or non-institutionalized, which involves physical and non-physical matters and requires infrastructure and skills or skills. Thus educational services are all activities related to education that prioritize service in the process.

As for the results of interviews with various sources, it was found that academic services during this pandemic were online, so all forms and all academics were carried out online, both lectures, exams, permits, including the processing of correspondence files, were carried out online to participate in breaking the chain COVID-19 was carried out to reduce physical contact during this pandemic crisis, but matters that require direct action are still served with several agreed-upon provisions based on health protocols through a task force that has been formed during a pandemic. This policy is issued by the leadership in the form of a Chief Circular, in addition to that the reference is based on an order from the Ministry of Education through the Directorate General of Higher Education regarding the implementation of learning at home, the second is the Governor Regulation regarding schools and learning at home including the Regent Regulation, which is the main reference for Orders from the Muhammadiyah Central Executive regarding learning and implementing lectures at home. From that basis, there are circular letters issued by the head of Universitas Muhammadiyah Sinjai rector regarding academic services that are online and not carried out in person. There are three forms of service carried out by the Universitas Muhammadiyah Sinjai, namely proposal examination services, lectures, and new student admissions.

Proposal examination services at the Universitas Muhammadiyah Sinjai during the COVID-19 pandemic were completely carried out online by making standard operating procedures, namely consultation with examiners and supervisors, and student representatives, the mechanism is the registration of exams using a google form, implementation using the Zoom meeting application to decide in this pandemic chain, the advantage is that online students can register anytime and anywhere, and the processing time is very fast. But on the other hand, the weakness in the network problem and the students' lack of understanding with its application and students do not pay attention to the time for proper communication.

Proposal examination services carried out online are fully carried out based on the procedures made by the exam committee, but the exam process is also influenced by a good internet network that can support the suitability of the time used. This is in terms of taking care of exam registration, then in the implementation of this exam, students should optimally be guided properly during the examination process until it is finished, because the use of the application used is still too early and has not been thoroughly known by students. 


\section{6 | Jurnal Administrare: Jurnal Pemikiran Ilmiah dan Pendidikan Administrasi Perkantoran \\ Volume 8 Issue 1, January-June 2021. Pages 143-148}

Lectures during the COVID-19 pandemic to break the chain of the spread of the corona disease virus are carried out online so that learning continues, this method is different from what is usually done face-to-face between students and teachers, lecturers and students.

During this pandemic, all learning activities or courses carried out online were carried out based on a leadership circular to prevent the spread of the coronavirus. Where students and lecturers carry out the learning process from home using group media on the WhatsApp application and other applications that can support the implementation of the learning process during this pandemic, the implementation of this lecture is very effective because students and lecturers do not have to be present on campus, this becomes the process. learning and teaching and on the other hand, student costs are not much just by having an internet quota to take classes using group media in the WhatsApp application, the learning process continues according to our expectations. There is also a way to collect student assignments besides using the WhatsApp group media, it can also be done by sending the assignment via email. So the implementation of this lecture also hones students' insights to use electronic media.

Online admission of new students is a must to provide easy and fast service according to the times. With the advancement of technological developments, online new student registration is also carried out at the Universitas Muhammadiyah Sinjai. The admission of new students this year is different from what was done in the previous year, this new student admission is done online, starting from registration, selection examinations, announcements, and later on, until the orientation for new student admissions is done online based on a circular from the Ministry of Education and Culture signed by Dirjen DIKTI. So we still use this guideline until now. It is our reference in implementing this new student admission. Then the priority is done, namely how to attract as many new student candidates as possible to register at Universitas Muhammadiyah Sinjai, one of them is by conducting socialization on social media, for example, by making videos that introduce and publish how to register online for prospective new students. Then in this new student admission process for registration using the Google form that has been made to facilitate prospective applicants, after registering, we enter into a group that uses group media on the WhatsApp application where we hope that all prospective students can receive important information about selection examination schedules, announcements and others related to new student admissions.

The impact of the COVID-19 pandemic has had a certain effect on various levels of society around the world. Due to the COVID-19 pandemic, social life around the world has changed a lot. Maintaining social distancing between people from being infected is the most important strategy for all countries. Many colleges have been closed to minimize the spread of this coronavirus infection. Close human contact is necessary for all learning processes in traditional dentistry education. Service methods must be innovated to continue to assist students in starting studies and completing studies (Chang et al., 2021)

Online service is a service that is carried out so that all service matters continue to run properly and should be with an easy method by keeping up with the times and besides this online service is a form of participation in preventing the spread of the COVID-19 outbreak in the campus area. This poses an intellectual challenge for further academic decision-making in the future during a pandemic (Mishra et al., 2020). During the COVID-19 pandemic, educational institutions around the world turned to online services. The main challenge remains in education related to student interaction. More support will be needed for agencies to meet these challenges as the recovery from the pandemic continues (Naroo et al., 2020). 


\section{CONCLUSION}

Academic services during the COVID-19 pandemic at the Universitas Muhammadiyah Sinjai ran effectively by established rules and were running according to the expected goals which could be proven by conformity to the measurement of the level of effectiveness, namely the achievement of goals, integration carried out in socializing forms effective services in breaking the chain of the spread of COVID-19, and conformity of policies based on the needs and capabilities of those served. Although in the focus of research on the effectiveness of academic services at the Universitas Muhammadiyah Sinjai, there are three types of services, namely serving the lecture proposal examination and admission service.

\section{REFERENCES}

Asbari, M., Novitasari, D., Pebrina, E. T., \& Santoso, J. (2020). Work-Family Conflict and Employee Performance during Covid-19 Pandemic: What is the Role of Mental Readiness to Change? JPBM (Jurnal Pendidikan Bisnis Dan Manajemen), 6(2).

Bao, W. (2020). COVID -19 and online teaching in higher education: A case study of Peking University . Human Behavior and Emerging Technologies. https://doi.org/10.1002/hbe2.191

Burki, T. K. (2020). COVID-19: consequences for higher education. In The Lancet. Oncology. https://doi.org/10.1016/S1470-2045(20)30287-4

Chang, T. Y., Hong, G., Paganelli, C., Phantumvanit, P., Chang, W. J., Shieh, Y. S., \& Hsu, M. L. (2021). Innovation of dental education during COVID-19 pandemic. Journal of Dental Sciences. https://doi.org/10.1016/j.jds.2020.07.011

Dennison Himmelfarb, C. R., \& Baptiste, D. (2020). Coronavirus Disease (COVID-19). Journal of Cardiovascular Nursing. https://doi.org/10.1097/jen.0000000000000710

Li, W., Yang, Y., Liu, Z. H., Zhao, Y. J., Zhang, Q., Zhang, L., Cheung, T., \& Xiang, Y. T. (2020). Progression of mental health services during the COVID-19 outbreak in China. International Journal of Biological Sciences. https://doi.org/10.7150/ijbs.45120

Miao, Q., Schwarz, S., \& Schwarz, G. (2021). Responding to COVID-19: Community volunteerism and coproduction in China. World Development. https://doi.org/10.1016/j.worlddev.2020.105128

Mishra, L., Gupta, T., \& Shree, A. (2020). Online teaching-learning in higher education during lockdown period of COVID-19 pandemic. International Journal of Educational Research Open. https://doi.org/10.1016/j.ijedro.2020.100012

Murphy, M. P. A. (2020). COVID-19 and emergency eLearning: Consequences of the securitization of higher education for post-pandemic pedagogy. Contemporary Security Policy. https://doi.org/10.1080/13523260.2020.1761749

Narmaditya, B. S., Prayitno, P. H., Wibowo, A., \& Agustina, Y. (2020). Blended Synchronous Learning and Students' Critical Thinking Ability: Lesson from Covid-19. JPBM (Jurnal Pendidikan Bisnis Dan Manajemen), 6(3). 
148 | Jurnal Administrare: Jurnal Pemikiran Ilmiah dan Pendidikan Administrasi Perkantoran Volume 8 Issue 1, January-June 2021. Pages 143-148

Naroo, S. A., Morgan, P. B., Shinde, L., \& Ewbank, A. (2020). The Impact of COVID-19 on Global Contact Lens Education. Journal of Optometry. https://doi.org/https://doi.org/10.1016/j.optom.2020.11.002

Oztig, L. I., \& Askin, O. E. (2020). Human mobility and coronavirus disease 2019 (COVID19): a negative binomial regression analysis. Public Health. https://doi.org/10.1016/j.puhe.2020.07.002

Shereen, M. A., Khan, S., Kazmi, A., Bashir, N., \& Siddique, R. (2020). COVID-19 infection: Origin, transmission, and characteristics of human coronaviruses. In Journal of Advanced Research. https://doi.org/10.1016/j.jare.2020.03.005

Suprianto, S., Arhas, S. H., \& Mahmuddin, M. (2020). The Effectiveness of Online Learning Amid the COVID-19 Pandemic. Jurnal Ad'ministrare, 7(2), 321-330.

Tirachini, A., \& Cats, O. (2020). COVID-19 and public transportation: Current assessment, prospects, and research needs. Journal of Public Transportation. https://doi.org/10.5038/2375-0901.22.1.1

Toquero, C. M. (2020). Challenges and Opportunities for Higher Education amid the COVID19 Pandemic: The Philippine Context. Pedagogical Research. https://doi.org/10.29333/pr/7947 